\title{
Konsep One River One Plan Dalam Penataan Kawasan DAS Binanga Lumbua Kabupaten Jeneponto
}

\author{
Despry Nur Annisa Ahmad ${ }^{1}$, Andi Idham Asman ${ }^{2}$, Ismah Pudji Rahayu Ishak ${ }^{3}$ \\ ${ }^{I}$ Teknik Perencanaan Wilayah dan Kota Universitas Muhammadiyah Bulukumba \\ ${ }^{2}$ Magister Perencanaan Wilayah dan Kota Institut Teknologi Bandung \\ ${ }^{3}$ Teknik Perencanaan Wilayah dan Kota Universitas Islam Negeri Alauddin Makassar \\ E-mail: 'desprynurannisa.ahmad@gmail.com, ${ }^{2}$ a.idhamasman@gmail.com, ${ }^{3}$ ismahpudjirahayuishak@gmail.com
}

\begin{abstract}
Abstrak
Kritisnya DAS Binanga Lumbua berkontribusi pada penurunan pendapatan perkapita Kabupaten Jeneponto. Ini juga menjadi salah satu alasan mengapa Kabupaten Jeneponto

\section{Kata Kunci}

DAS; Kekeringan; Banjir; Konsep Penataan DAS; Pembangunan Berkelanjutan. menjadi satu-satunya wilayah di Provinsi Sulawesi Selatan yang termasuk dalam kategori daerah tertinggal. Jika melihat kondisi fisik wilayah ini yang mempunyai topografi variatif dan tanah yang subur, semestinya wilayah ini memiliki nilai ekonomi yang potensial untuk pengembangan hutan, tanaman perkebunan, maupun pertanian tanaman pangan. Hasil penelitian sebelumnya adalah identifikasi kekeringan dengan menggunakan pendekatan hidrologis secara kualitatif dan kuantitatif. Kemudian, memberikan arahan pemanfaatan ruang yang berbasis pada upaya pencegahan bencana kekeringan. Sehingga dalam penelitian lanjutan ini, tujuan yang akan dicapai adalah merancang konsep one river one plan dalam penataan DAS Binanga Lumbua secara komperehensif untuk mewujudkan pembangunan yang berkelanjutan. Analisis yang digunakan adalah berupa analisis spasial dan deskriptif kualitatif. Hasil penelitian ini berupa pemetaan konsep penataan DAS yang berbentuk site plan.
\end{abstract}

$\begin{array}{ll} & \text { Abstract } \\ & \text { The criticality of the Binanga Lumbua watershed is that it contributes to the decline in the } \\ \text { Keywords } & \text { income per capita of Jeneponto Regency. This is also one of the reasons why Jeneponto } \\ \text { Watershed; } & \text { Regency is the only area in South Sulawesi Province that is included in the category of } \\ \text { drought; flood; } & \text { underdeveloped areas. Looking at the physical condition of this area which has a varied } \\ \text { watershed } & \text { topography and fertile soil, this area should have potential economic value for the } \\ \text { management } & \text { development of forestry, plantation crops, and food crop agriculture. The results of previous } \\ \text { concept; } & \text { research were the identification of drought using a hydrological approach both qualitatively } \\ \text { sustainable } & \text { and quantitatively. Then, provide directions for spatial use based on drought prevention } \\ \text { development. } & \text { efforts. So that in this follow-up research, the goal to be achieved is to design a 'one river one } \\ \text { plan concept' in the comprehensive arrangement of the Binanga Lumbua watershed to realize } & \text { sustainable development. The analysis used is in the form of qualitative descriptive and spatial } \\ \text { analysis. The result of this research is a mapping of the watershed planning concept in the } \\ \text { form of a site plan. }\end{array}$

\section{PENDAHULUAN}

Indonesia adalah negara yang memiliki potensi sumberdaya air yang melimpah. Tercatat bahwa negara ini memiliki 458 Daerah Aliran Sungai. Daerah Aliran Sungai atau yang sering disebut dengan singkatan DAS adalah suatu ekosistem sekaligus sistem hidrologi dimana seluruh air yang mengalir bermuara pada outlet yang tunggal (Wani SP dan Garg K, 2008). DAS merupakan suatu ekosistem berarti bahwa pembahasan DAS tidak sebatas tentang unit hidrologi yang ada tetapi juga harus membahas tentang aspek sosial, ekologi, ekonomi, dan kebijakan yang diberlakukan di DAS tersebut. Adapun DAS sebagai suatu kesatuan tata air, yakni berarti bahwa DAS terdiri dari tiga zona yakni zona hulu yang berfungsi untuk memproduksi/menangkap air hujan, zona tengah sebagai zona untuk menyimpan air, dan zona hilir untuk menyalurkan ke laut atau danau melalui satu sungai utama (Noordwijk et al, 2014). Fungsi dari keberadaan air yang ada di DAS ini selain untuk kebutuhan harian bagi seluruh makhluk hidup (Yen et al, 2014), juga dapat dijadikan sebagai pembangkit listrik tenaga air, seperti yang telah dilakukan di Negara China (Bach et,al., 2011) bahkan juga dapat dijadikan sebagai media transportasi (Fisu, 2016). Perubahan lahan di daerah aliran sungai (DAS) saat ini sangat berdampak pada banyaknya pengikisan/erosi di daerah hulu sampai ke hilir sungai (Eryani, 2014). 
Begitu besarnya peran penting yang dimiliki oleh suatu kawasan DAS, maka dapat dikatakan bahwa kawasan ini merupakan kawasan vital yang tidak boleh disepelehkan dalam merencanakan ataupun mengembangkan suatu wilayah (Halim, 2014). Hal tersebut karena lingkungan DAS yang baik akan memberi penghidupan yang baik bagi para penghuni yang mendiaminya, dan hal sebaliknya terjadi jika lingkungan DAS tersebut tidak baik atau kritis (Amin, Sarino \& Sari, 2015).

Problematika inilah yang kemudian ditemukan pada salah satu kawasan DAS di Indonesia, tepatnya di Kabupaten Jeneponto Provinsi Sulawesi Selatan. DAS tersebut adalah DAS Binanga Lumbua. Saat ini, DAS Binanga Lumbua terindikasi menjadi DAS kritis (Ahmad dkk, 2016). Luas DAS adalah 13.058 Ha dan melintasi 3 kecamatan di Kabupaten Jeneponto, yaitu Kecamatan Bangkala, Bangkala Barat, dan Bonto Ramba. Seluas 12.181 Ha, Kawasan DAS ini berada di Kecamatan Bangkala dan selebihnya 87 Ha berada di Kecamatan Bangkala Barat dan Bontoramba. Besarnya cakupan wilayah DAS yang melintasi Kecamatan Bangkala ini, menjadikan kekritisan yang terjadi sangat berpengaruh pada pendapatan perkapita masyarakat setempat.

Penurunan pendapatan perkapita di wilayah tersebut juga berkontribusi pada penurunan pendapatan perkapita skala kabupaten karena wilayah ini dalam Peraturan Daerah Kabupaten Jeneponto Nomor 1 Tahun 2012 tentang Rencana Tata Ruang Wilayah Tahun 2011-2031 memiliki hirarki sebagai Pusat Kegiatan Wilayah (PKW). Suatu lokasi yang memiliki hirarki sebagai PKW, memiliki fungsi sebagai pusat kegiatan industri dan jasa dan menjadi lokasi simpul kegiatan ekspor-impor. Namun pada kondisi yang ada sekarang ini, Kecamatan Bangkala yang di justifikasi sebagai lokasi PKW mengalami permasalahan krisis. Tentunya hal ini akan berdampak langsung pada konstelasi perekonomian kabupaten. Hal inilah yang kemudian juga menjadi salah satu alasan mengapa Kabupaten Jeneponto menjadi satu-satunya wilayah di Provinsi Sulawesi Selatan yang termasuk dalam kategori daerah tertinggal berdasarkan Keputusan Peraturan Presiden Republik Indonesia Nomor 131 Tahun 2015 tentang Penetapan Daerah Tertinggal Tahun 2015-2019.

Berdasarkan data Badan Pusat Statistik Kabupaten Jeneponto Tahun 2015, tercatat bahwa rumah tangga miskin di wilayah ini berjumlah $8.289 \mathrm{KK}$ atau $71,60 \%$ dari total keseluruhan. Ketika mencocokkan data dengan melihat kondisi lapangan, rumah tangga penduduk miskin berada di wilayah DAS bagian tengah dengan mata pencaharian yang paling dominan adalah sebagai petani.

Jika melihat kondisi fisik wilayah ini yang mempunyai topografi variatif dan tanah yang subur, semestinya wilayah ini memiliki nilai ekonomi yang potensial untuk pengembangan hutan, tanaman perkebunan, maupun pertanian tanaman pangan. Selain itu, wilayah ini juga Namun dalam kenyataannya, hal tersebut tidak terjadi karena wilayah ini sering mengalami kekeringan panjang pada musim kemarau dan bencana banjir pada musim hujan.

Selain bencana banjir dan kekeringan yang terjadi di wilayah ini, terdapat juga potensi bencana longsor yang akan terjadi pada penelitian ini. Berdasarkan hal tersebut, maka dilakukan penelitian yang berjudul Konsep One River One Plan dalam penataan DAS Binanga Lumbua agar dapat mewujudkan pembangunan yang berkelanjutan dengan melakukan perencanaan penggunanaan lahan secara komperehensif di Kawasan DAS Binanga Lumbua dengan berbasis pada kompilasi data permasalahan potensi bencana alam.berdasarkan ketersediaan data yang diperoleh kawasan DAS ini.

Tujuan Penulisan berdasarkan rumusan masalah diatas, tujuan penulisan penelitian ini adalah sebagai menganalisis dan memvisualisasikan konsep one river one plan dalam penataan DAS Binanga Lumbua Kabupaten Jeneponto.

Adapun sasaran dari penulisan ini adalah sebagai berikut:

a) Sasaran Praktis

Penelitian ini diharapkan dapat menjadi bahan masukan tambahan pada saat proses revisi RTRW Kabupaten Jeneponto dilaksanakan. Penelitian ini juga diharapkan dapat menjadi bahan masukan tambahan pada program pengelolaan DAS yang dilaksanakan oleh Dinas Kehutanan Kabupaten Jeneponto serta bisa menjadi langkah awal agar Kabupaten Jeneponto tidak lagi menduduki posisi sebagai wilayah tertinggal pada penilaian perpes berikutnya.

b) Sasaran Teoritik

Konsep One River One Plan ini merupakan pengembangan dari teori Integrated River Basin Management (IRBM) yang dilakukan oleh tim peneliti.

Kerangka Berpikir 


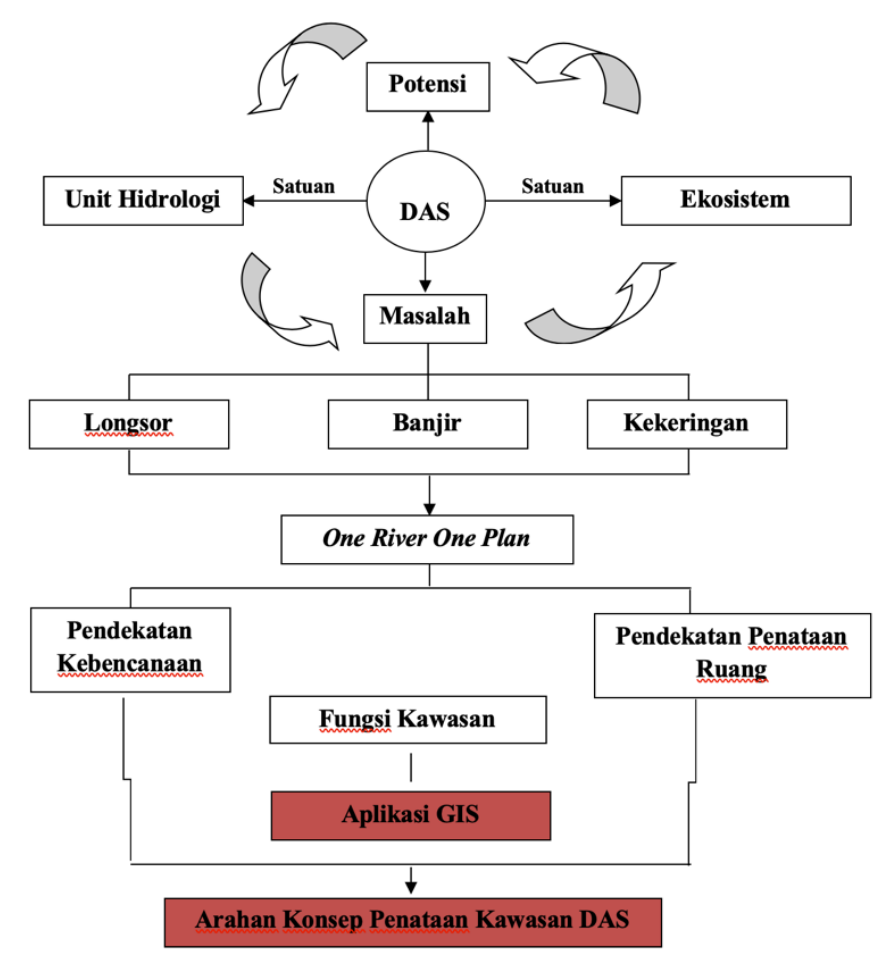

Gambar 1. Kerangka Berpikir

Sumber: Hasil Olah Pustaka

\section{KOMPILASI DATA}

A. Metode Pengumpulan Data dan Pengolahan Data

Metode pengumpulan data yang digunakan dalam penelitian adalah dengan cara observasi/survey lapangan, wawancara, dan studi kepustakaan. Adapun metode analisis untuk kepentingan pengolahan data yang digunakan adalah berupa deskrpitif kualitatif dan analisis spasial.

1. Analisis Deskriptif Kualitatif

Analisis deskriptif kualitatif adalah analisis yang dilakukan dengan mendeskripsikan kondisi atau keadaan yang terjadi dilapangan, dimana data dan informasi tersebut tidak dapat dianalisa secara kuantitatif, sehingga memerlukan penjelasan melalui pembahasan.

2. Analisis Spasial

Analisis spasial adalah metode analisis yang dilakukan dengan melakukan analisis berbasis pada datadata spasial yang tersedia. Teknik yang digunakan dalam analisis penelitian ini adalah teknik overlay, yaitu penggabungan berbagai peta individu (memiliki informasi/database yang spesifik). Teknik overlay digunakan untuk menentukan potensi keberadaan air tanah dalam cakupan tinjauan kekeringan DAS secara kualitatif di DAS Binanga Lumbua dengan menggunakan parameter hidrogeomorfologi dan hal ini telah dilakukan pada penelitian sebelumnya, kemudian selanjutnya pada penelitian ini melakukan penentuan zona rawan longsor, menentukan zona rawan banjir, dan menentukan arahan pemanfaatan ruang DAS berdasarkan parameter fungsi kawasan yang telah ditetapkan. Selengkapnya untuk masing-masing skoring dari nilai masing-masing parameter dapat dilihat pada uraian berikut.

a. Parameter penilaian keberadaan potensi air tanah

Parameter penilaian yang digunakan untuk mengetahui keberadaan potensi keberadaan air tanah di Kawasan DAS Binanga Lumbua adalah berupa kemiringan lereng, klasifikasi intensitas hujan, kelas penutup lahan, tekstur tanah, permeabilitas tanah, infiltrasi tanah, dan batuan penyusun akuifer. Adapun rincian penilaiannya dapat dilihat pada Tabel 1 sampai Tabel 7 berikut

Tabel 1. Kelas dan Kriteria Kemiringan Lereng

\begin{tabular}{cccc}
\hline No. & \multicolumn{1}{c}{ Kelas } & Kemiringan Lereng $\left({ }^{\circ}\right)$ & Harkat \\
\hline 1 & Agak curam & $>30$ & 1 \\
2 & Miring & $15-30$ & 2 \\
\hline
\end{tabular}




\begin{tabular}{clcc}
\hline No. & \multicolumn{1}{c}{ Kelas } & Kemiringan Lereng $\left({ }^{\circ}\right)$ & Harkat \\
\hline 3 & Agak miring & $8-15$ & 3 \\
4 & Landau & $3-8$ & 4 \\
5 & Datar & $0-3$ & 5 \\
\hline
\end{tabular}

Sumber: Arsyad, 1989

Tabel 2. Klasifikasi Intensitas Hujan

\begin{tabular}{clcc}
\hline No. & \multicolumn{1}{c}{ Kelas } & $\begin{array}{c}\text { Intensitas Hujan Harian Rata- } \\
\text { rata (mm/hari) }\end{array}$ & Harkat \\
\hline 1 & Sangat rendah & $<13,6$ & 1 \\
2 & Rendah & $13,6-20,7$ & 2 \\
3 & Sedang & $20,7-27,7$ & 3 \\
4 & Tinggi & $27,7-34,8$ & 4 \\
5 & Sangat tinggi & $>34,8$ & 5 \\
\hline \multicolumn{3}{c}{ Sumber: Arsyad, 1989} \\
\end{tabular}

Tabel 3. Klasifikasi Penutup Lahan

\begin{tabular}{lcc}
\hline \multicolumn{1}{c}{ Kondisi Penutup Lahan } & Tingkat Kerapatan & Harkat \\
\hline $\begin{array}{l}\text { Penutup vegetasi tidak efektif (5\% luas } \\
\text { daerah bervegetasi baik) }\end{array}$ & Sangat Jarang & 1 \\
$\begin{array}{l}\text { Penutup vegetasi rendah (10\% luas } \\
\text { daerah bervegetasi baik) }\end{array}$ & Jarang & 2 \\
$\begin{array}{l}\text { Penutup vegetasi sedang (15\% luas } \\
\text { daerah bervegetasi baik) }\end{array}$ & Sedang & 3 \\
$\begin{array}{l}\text { Penutup vegetasi tinggi (20\% luas } \\
\text { daerah bervegetasi baik) }\end{array}$ & Lebat & 4 \\
$\begin{array}{l}\text { Penutup vegetasi sangat tinggi (25\% } \\
\text { luas daerah bervegetasi baik) }\end{array}$ & Sangat Lebat & 5 \\
\hline
\end{tabular}

Sumber: Arsyad, 1989

Tabel 4. Kelas dan Kriteria Tekstur Tanah

\begin{tabular}{|c|c|c|c|}
\hline No. & Kelas & Kelas Tekstur Tanah & Harkat \\
\hline 1 & Jelek & $\begin{array}{l}\text { Lempung bergeluh, lempung berpasir } \\
\text { halus, geluh berlempung }\end{array}$ & 1 \\
\hline 2 & Sangat Jelek & Lempung, lempung berdebu & 2 \\
\hline 3 & Sedang & $\begin{array}{l}\text { Debu, geluh, geluh berdebu, geluh } \\
\text { lempung berdebu, geluh lempung } \\
\text { berpasir, lempung berpasir }\end{array}$ & 3 \\
\hline 4 & Baik & $\begin{array}{l}\text { Geluh berpasir, geluh pasir } \\
\text { berlempung, geluh pasir berdebu }\end{array}$ & 4 \\
\hline 5 & Sangat Baik & $\begin{array}{l}\text { Pasir berlempung, pasir berdebu, } \\
\text { pasir bergeluh, pasir }\end{array}$ & 5 \\
\hline
\end{tabular}

Sumber: Arsyad, 1989

Tabel 5. Kelas Permeabilitas Tanah

\begin{tabular}{clcc}
\hline No. & \multicolumn{1}{c}{ Kelas } & Kecepatan $(\mathrm{cm} / \mathrm{jam})$ & Harkat \\
\hline 1 & Sangat Lambat & $<0,5$ & 1 \\
2 & Lambat & $0,5-2,0$ & 2 \\
3 & Lambat sampai Sedang & $2,0-6,25$ & 3 \\
4 & Sedang & $6,25-12,5$ & 4 \\
5 & Sangat sampai cepat & $>12,5$ & 5 \\
\hline
\end{tabular}

Sumber: Arsyad, 1989

Tabel 6. Kelas Infiltrasi

\begin{tabular}{cccc}
\hline Tekstur Tanah & $\begin{array}{c}\text { Tingkat } \\
\text { Infiltrasi }\end{array}$ & Kelas Metode Cook & Harkat \\
\hline
\end{tabular}




\begin{tabular}{lclc}
\hline \multicolumn{1}{c}{ Tekstur Tanah } & $\begin{array}{c}\text { Tingkat } \\
\text { Infiltrasi }\end{array}$ & Kelas Metode Cook & Harkat \\
\hline $\begin{array}{l}\text { Batuan dengan lapisan } \\
\text { tanah tipis }\end{array}$ & Tidak efektif & $\begin{array}{l}\text { Tidak ada penutup } \\
\text { tanah efektif, batuan } \\
\text { padatan tipis }\end{array}$ & 1 \\
$\begin{array}{l}\text { Lempung bergeluh, } \\
\text { lempung berpasir halus, } \\
\text { geluh berlempung, } \\
\text { lempung berdebu, } \\
\text { lempung }\end{array}$ & Lambat & $\begin{array}{l}\text { Infiltrasi lambat, } \\
\text { tanah lempung }\end{array}$ & 2 \\
$\begin{array}{l}\text { Debu, geluh, geluh } \\
\text { berdebu, geluh lempung } \\
\text { berdebu, geluh lempung } \\
\text { berpasir, lempung } \\
\text { berpasir }\end{array}$ & Normal & $\begin{array}{l}\text { Tanah geluh, tanah } \\
\text { bertekstur liat }\end{array}$ & 3 \\
$\begin{array}{l}\text { Geluh berpasir, geluh } \\
\text { pasir berdebu, geluh, } \\
\text { geluh pasir berlempung }\end{array}$ & Agak tinggi & $\begin{array}{l}\text { Pasir, tanah } \\
\text { terintegrasi baik }\end{array}$ & 4 \\
$\begin{array}{l}\text { Pasir berlempung, pasir } \\
\text { berdebu, pasir bergeluh, } \\
\text { pasir }\end{array}$ & Tinggi & $\begin{array}{l}\text { Pasir dalam, tanah } \\
\text { terintegrasi baik }\end{array}$ & 5 \\
\hline
\end{tabular}

Sumber: Arsyad, 1989

Tabel 7. Klasifikasi Batuan Penyusun Akuifer

\begin{tabular}{|c|c|c|c|c|}
\hline No. & Kelas & Batuan & Sy & Harkat \\
\hline 1 & Sangat Jelek & Lempung & $3-7,46$ & 1 \\
\hline 2 & Jelek & Lanau, batu lanau & $7,47-12,6$ & 2 \\
\hline 3 & Sedang & Batugamping & $12,61-17,73$ & 3 \\
\hline 4 & Baik & $\begin{array}{l}\text { Tuff, Batupasir } \\
\text { halus }\end{array}$ & $17,74-22,86$ & 4 \\
\hline 5 & Sangat Baik & $\begin{array}{l}\text { Kerakal kasar, } \\
\text { kerakal, kerikil, } \\
\text { pasir kasar, pasir } \\
\text { sedang, pasir halus, } \\
\text { dan batupasir } \\
\text { sedang }\end{array}$ & $22,87-28$ & 5 \\
\hline
\end{tabular}

b. Parameter penilaian potensi bencana longsor

Parameter penilaian yang digunakan untuk mengetahui keberadaan potensi keberadaan potensi bencana tanah longsor di Kawasan DAS Binanga Lumbua adalah berupa kemiringan lereng, curah hujan, jenis tanah, jenis batuan, dan penggunaan lahan. Rincian penilaiannya dapat dilihat pada Tabel 8 sampai Tabel 12 berikut ini.

Tabel 8. Skor Kemiringan Lereng

\begin{tabular}{|c|c|c|c|c|}
\hline No. & Kemiringan Lereng & Harkat & $\begin{array}{c}\text { Bobot } \\
\text { Indikator }\end{array}$ & Skor \\
\hline 1. & Kemiringan lereng $41-60 \%$ & 6 & \multirow{6}{*}{5} & 30 \\
\hline 2. & Kemiringan lereng $26-40 \%$ & 5 & & 25 \\
\hline 3. & Kemiringan lereng $16-25 \%$ & 4 & & 20 \\
\hline 4. & Kemiringan lereng $9-15 \%$ & 3 & & 15 \\
\hline 5. & Kemiringan lereng $2-8 \%$ & 2 & & 10 \\
\hline 6. & Kemiringan lereng $<2 \%$ & 1 & & 5 \\
\hline
\end{tabular}


Tabel 9. Skor Curah Hujan

\begin{tabular}{|c|l|c|c|c|}
\hline No. & \multicolumn{1}{|c|}{ Curah Hujan } & Harkat & $\begin{array}{c}\text { Bobot } \\
\text { Indikator }\end{array}$ & Skor \\
\hline 1. & Curah Hujan Tahunan $3000-3500 \mathrm{~mm}$ & 4 & & 16 \\
\hline 2. & Curah Hujan Tahunan $2500-3000 \mathrm{~mm}$ & 3 & \multirow{2}{*}{4} & 12 \\
\hline 3. & Curah Hujan Tahunan $2000-2500 \mathrm{~mm}$ & 2 & & 8 \\
\hline 4. & Curah Hujan Tahunan $1000-2000 \mathrm{~mm}$ & 1 & & 4 \\
\hline
\end{tabular}

Sumber: Permen PU No. 22 Tahun 2007 dengan modifikasi penulis

Tabel 10. Skor Jenis Tanah

\begin{tabular}{|c|l|c|c|c|}
\hline No. & \multicolumn{1}{|c|}{ Tanah } & Harkat & $\begin{array}{c}\text { Bobot } \\
\text { Indikator }\end{array}$ & Skor \\
\hline 1. & Podsolik, Andosol & 4 & & 12 \\
\hline 2. & Grumosol, Brown Forest, Mediteran & 3 & \multirow{2}{*}{3} & 9 \\
\hline 3. & Latosol & 2 & & 6 \\
\hline 4. & Aluvial & 1 & & 3 \\
\cline { 1 - 2 }
\end{tabular}

Sumber: Permen PU No. 22 Tahun 2007 dengan modifikasi penulis

Tabel 11. Skor Batuan

\begin{tabular}{|c|l|c|c|c|}
\hline No. & \multicolumn{1}{|c|}{ Batuan } & Harkat & $\begin{array}{c}\text { Bobot } \\
\text { Indikator }\end{array}$ & Skor \\
\hline 1. & $\begin{array}{l}\text { Batu Sedimen: Batu Pasir, Tuf } \\
\text { Batuan Lempung, Tuf Batu Pasir, } \\
\text { Batu Gamping }\end{array}$ & 3 & & 12 \\
\hline 2. & Batuan Malihan: Marmer Gamping & 2 & & 8 \\
\hline 3. & Batuan Beku: Basalt, Andesit & 1 & & 4 \\
\cline { 2 - 2 }
\end{tabular}

Sumber: Permen PU No. 22 Tahun 2007 dengan modifikasi penulis

Tabel 12. Skor Penggunaan Lahan

\begin{tabular}{|c|l|c|c|c|}
\hline No. & \multicolumn{1}{|c|}{ Penggunaan Lahan } & Harkat & $\begin{array}{c}\text { Bobot } \\
\text { Indikator }\end{array}$ & Skor \\
\hline 1. & Tanah Terbuka & 6 & & 30 \\
\hline 2. & Perkebunan Lahan Kering & 5 & & 25 \\
\hline 3. & Perkebunan Lahan Kering dan Semak & 4 & \multirow{2}{*}{5} & 20 \\
\hline 4. & Semak Belukar & 3 & & 15 \\
\hline 5. & Hutan Sekunder & 2 & & 10 \\
\hline 6. & Hutan Rapat & 1 & & 5 \\
\hline 7. & Tubuh Air & 0 & & 0 \\
\hline
\end{tabular}

Sumber: Permen PU No. 22 Tahun 2007 dengan modifikasi penulis

c. Parameter penilaian potensi bencana banjir

Parameter penilaian yang digunakan untuk mengetahui keberadaan potensi bencana banjir di Kawasan DAS Binanga Lumbua adalah berupa kemiringan lereng, curah hujan, infiltrasi tanah, dan penggunaan lahan. Rincian penilaiannya dapat dilihat pada Tabel 13 sampai Tabel 16 berikut ini.

Tabel 13. Klafikasi Kemiringan Lereng

\begin{tabular}{|c|c|c|c|c|c|}
\hline No. & Kemiringan Lereng (\%) & $\begin{array}{c}\text { Kelas } \\
\text { Kelerengan }\end{array}$ & Harkat & Bobot & Skor \\
\hline 1. & Datar dan sedikit landai & $0-8 \%$ & 5 & \multirow{2}{*}{3} & 15 \\
\hline 2. & Bergelombang sampai Berbukit & $9-15 \%$ & 4 & & 12 \\
\hline
\end{tabular}




\begin{tabular}{|c|c|c|c|c|}
\hline 3. & Berbukit & $16-25 \%$ & 3 & 9 \\
\hline 4. & Berbukit sampai Bergunung & $26-40 \%$ & 2 & 6 \\
\hline 5. & Bergunung & $>40 \%$ & 1 & 3 \\
\hline
\end{tabular}

Sumber : Gunawan (1991) dan suprojo dalam Eko Kustiyanto (2004), dengan modifikasi penulis

Tabel 14. Intensitas Curah Hujan

\begin{tabular}{|c|l|c|c|c|}
\hline No. & Rata-rata Curah Hujan Bulanan & Harkat & Bobot & Skor \\
\hline 1. & & 5 & & 15 \\
\cline { 1 - 2 } & $>3000 \mathrm{~mm} / \mathrm{th}$ & 4 & & 12 \\
\cline { 1 - 2 } & $2501-3000 \mathrm{~mm} / \mathrm{th}$ & 3 & \multirow{3}{*}{3} & 9 \\
\hline 4. & $2001-2500 \mathrm{~mm} / \mathrm{th}$ & 2 & & 6 \\
\hline 5. & $1501-2000 \mathrm{~mm} / \mathrm{th}$ & 1 & & 3 \\
\hline
\end{tabular}

Sumber : Kriteria \& Standar Teknik Kementerian PU, dengan modifikasi penulis

Tabel 15. Klasifikasi Infiltrasi Tanah

\begin{tabular}{|c|c|c|c|c|c|}
\hline No. & Tekstur & Jenis & Harkat & Bobot & Skor \\
\hline 1. & Halus & Grumusol & 5 & \multirow{5}{*}{2} & 10 \\
\hline 2. & Agak Halus & $\begin{array}{l}\text { Litosil, } \\
\text { Mediteran }\end{array}$ & 4 & & 8 \\
\hline 3. & Sedang & Latosol & 3 & & 6 \\
\hline 4. & Agak Kasar & $\begin{array}{l}\text { Andosol, } \\
\text { Alluvial }\end{array}$ & 2 & & 4 \\
\hline 5. & Kasar & Regosol & 1 & & 2 \\
\hline
\end{tabular}

Sumber : Gunawan (1991) dan suprojo dalam Eko Kustiyanto (2004), dengan modifikasi penulis

Tabel 16. Klasifikasi Penggunaan Lahan

\begin{tabular}{|c|l|c|c|c|}
\hline No. & \multicolumn{1}{|c|}{ Penggunaan Lahan } & Harkat & Bobot & Skor \\
\hline 1. & Permukiman, Sungai & 5 & & 10 \\
\hline 2. & Sawah, Tambak, Danau, Rawa & 4 & & 8 \\
\cline { 1 - 2 } & Hutan Mangrove & 3 & \multirow{2}{*}{2} & 6 \\
\hline 4. & Kebun Campuran, Ladang, Tegalan & 2 & & 4 \\
\hline 5. & Hutan, Padang Rumput, Semak Belukar & 1 & & 2 \\
\hline
\end{tabular}

Sumber : Meijerink (1970) dalam Eko Kustiyanto (2004), dengan modifikasi penulis 
Tabel 17. Pembagian Kelas Tingkat Kerawanan Banjir

\begin{tabular}{|c|l|c|}
\hline No & \multicolumn{1}{|c|}{ Tingkat Kerentanan } & Skor Nilai \\
\hline 1 & Sangat Rentan & $>39$ \\
\hline 2 & Rentan & $37-39$ \\
\hline 3 & Agak Rentan (Sedang) & $34-36$ \\
\hline 4 & Kurang Rentan & $31-33$ \\
\hline 5 & Tidak Rentan & $<31$ \\
\hline
\end{tabular}

\section{Sumber: Hasil Perhitungan}

d. Parameter Penilaian Penetapan Fungsi Kawasan

Parameter penilaian yang digunakan untuk menentukan fungsi kawasan di Kawasan DAS Binanga Lumbua adalah berupa kemiringan lereng, jenis tanah, intensitas curah, sempadan sungai, dan sempadan mata air. Adapun rincian penilaiannya dapat dilihat pada Tabel 18 sampai Tabel 22 sebagai berikut.

Tabel 18. Harkat Kemiringan Lereng

\begin{tabular}{cccc}
\hline \multirow{2}{*}{ Kelas } & $\begin{array}{c}\text { Kemiringan Lereng } \\
(\%)\end{array}$ & Keterangan & Skor \\
\hline 1 & $0-8$ & Datar & 20 \\
2 & $8-15$ & Landai & 40 \\
3 & $15-25$ & Agak Curam & 60 \\
4 & $25-45$ & Curam & 80 \\
5 & $>45$ & Sangat Curam & 100 \\
\hline
\end{tabular}

Sumber: Departemen Kimpraswil (2007)

Tabel 19. Harkat Jenis Tanah

\begin{tabular}{cllc}
\hline Kelas & \multicolumn{1}{c}{ Jenis Tanah } & Keterangan & Bobot \\
\hline 1 & $\begin{array}{l}\text { Aluvial, tanah glei, planosol, } \\
\text { hidromorf kelabu, laterik tanah }\end{array}$ & Tidak peka & 15 \\
2 & Latosol & Agak peka & 30 \\
3 & $\begin{array}{l}\text { Brown forest soil, non-calcic } \\
\text { brown, mediteran }\end{array}$ & Peka & 45 \\
4 & $\begin{array}{l}\text { Andosol, laterit, grumosol } \\
\text { podsol, podsolic }\end{array}$ & Kurang peka & 60 \\
5 & $\begin{array}{l}\text { Regosol, litosol, organosol, } \\
\text { renzina }\end{array}$ & Sangat peka & 75 \\
\hline
\end{tabular}

Sumber: Departemen Kimpraswil (2007)

Tabel 20. Harkat Intensitas Curah Hujan

\begin{tabular}{cccc}
\hline Kelas & Curah Hujan (mm/hari) & Keterangan & Bobot \\
\hline 1 & $<13,60$ & Sangat rendah & 10 \\
2 & $13,61-20,70$ & Rendah & 20 \\
3 & $20,71-27,70$ & Sedang & 30 \\
4 & $27,71-34,80$ & Tinggi & 40 \\
5 & $>34,80$ & Sangat tinggi & 50 \\
\hline
\end{tabular}

Tabel 21. Harkat Sempadan Sungai

\begin{tabular}{cclc}
\hline Kelas & Sempadan Sungai $(\mathrm{m})$ & Keterangan & Bobot \\
\hline 1 & 15 & Pemukiman & 175 \\
2 & 50 & Sangat kecil & 175 \\
3 & 100 & Sangat besar & 175 \\
\hline
\end{tabular}

Sumber: Departemen Kimpraswil (2007)

Tabel 22. Harkat Sempadan Mata Air 


\begin{tabular}{cccc}
\hline Kelas & Sempadan Mata Air $(\mathrm{m})$ & Keterangan & Bobot \\
\hline 1 & 15 & Pemukiman & 175 \\
2 & 200 & Non Pemukiman & 175 \\
\hline \multicolumn{4}{c}{ Sumber: Departemen Kimpraswil (2007) }
\end{tabular}

\section{PEMBAHASAN}

DAS Binanga Lumbua memiliki luas wilayah secara keseluruhan 13.058 Ha. DAS Binanga Lumbua ini melintasi 3 kecamatan, yaitu Kecamatan Bangkala Barat, Kecamatan Bontoramba, dan Kecamatan Bangkala. Namun, sebagian besar wilayah DASnya berada di Kecamatan Bangkala yaitu 12.181 Ha dan selebihnya 87 Ha berada di Kecamatan Bangkala Barat dan Bontoramba. Karena sebagian besar wilayah ini berada pada Kecamatan Bangkala, maka untuk arahan spasial plan dari kebijakan pemerintah difokuskan pada kedudukan Kecamatan Bangkala ini dalam konstelasi wilayah di Kabupaten Jeneponto. Terkait kondisi iklim, DAS Binanga Lumbua termasuk daerah beriklim tropis dengan suhu rata-rata diatas $26^{\circ} \mathrm{C}$. Curah hujan terendah $1.049 \mathrm{~mm} /$ tahun dan tertinggi $3.973 \mathrm{~mm} /$ tahun. Jenis tanahnya terdapat empat macam yaitu mediteran, grumosol, aluvial, dan laterit. Jenis lahan eksisting yang paling dominan di kawasan ini adalah berupa lahan tegalan dengan luas 2.853 Ha dan tutupan lahan yang paling sedikit adalah berupa tambak dengan luas lahan 233 Ha. Selengkapnya tentang tutupan lahan di DAS Binanga Lumbua dapat dilihat pada Tabel 12 berikut.

Tabel 23. Tutupan Lahan

\begin{tabular}{lrr}
\hline \multicolumn{1}{c}{ Tutupan Lahan } & $\begin{array}{c}\text { Luas } \\
(\mathrm{Ha})\end{array}$ & Pesentase (\%) \\
\hline Hutan & 178 & 1,36 \\
Hutan Bakau & 165 & 1,26 \\
Kebun / Perkebunan & 2.246 & 17,20 \\
Lahan Terbangun/Permukiman & 1.274 & 9,76 \\
Sawah Irigasi & 1.461 & 11,19 \\
Sawah Tadah Hujan & 1.742 & 13,34 \\
Semak Belukar/Alang Alang & 2.249 & 17,22 \\
Sungai & 657 & 5,03 \\
Tambak & 233 & 1,78 \\
Tegalan & 2.853 & 21,85 \\
& 13.058 & 100 \\
\hline \multicolumn{2}{c}{ Jumlah } &
\end{tabular}

Sumber: Perhitungan GIS Tahun 2016

Berangkat dari keresahan yang terjadi akibat bencana kekeringan dan bencana banjir yang terjadi di lokasi ini, maka dilakukanlah penelitian awal sebelumnya untuk mengidentifikasi kekeringan dengan tinjauan hidrologis. Identifikasi kekeringan secara kualitatif dilakukan dengan teknik overlay dengan parameter yang telah disebutkan pada pembahaan sebelumnya. Metode kualitatif ini bertujuan untuk mengetahui ketersediaan air tanah berdasarkan faktor fisik lahan dengan parameter hidrogeomorfologi yang dimiliki oleh Kawasan DAS Binanga Lumbua. Hasil analisis overlay yang telah dilakukan dapat dilihat pada Gambar 10 berikut. 


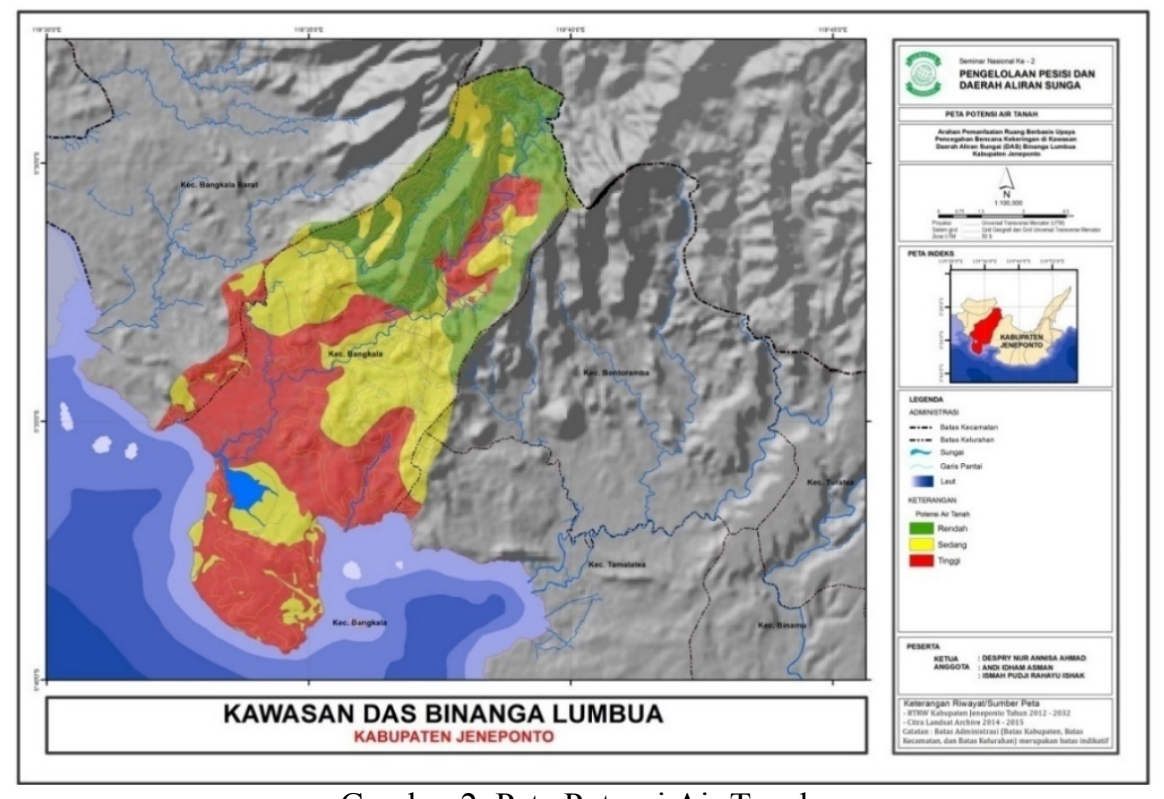

Gambar 2. Peta Potensi Air Tanah

Sumber: Ahmad.,dkk, 2016

Berdasarkan peta potensi air tanah diatas, dapat diketahui bahwa kawasan hilir dan tengah DAS memiliki tingkat ketersediaan air tanah sedang hingga tinggi. Namun, berbeda halnya yang terjadi pada hulu DAS. Pada hulu DAS, tingkat ketersediaan air tanahnya rendah.

Setelah mengetahui tentang potensi air tanah di lokasi penelitian, maka hal lanjutan yang dilakukan adalah menentukan zona rawan bencana lainnya. Berdasarkan ketersediaan data dilapangan, maka bencana lainnya yang dimaksud adalah bencana longsor dan bencana banjir.

\section{Hasil Analisis Pemetaan Bencana Lonsor}

Berdasarkan hasil analisis yang dilakukan, wilayah DAS yang memiliki potensi bencana longsor yang tinggi adalah wilayah bagian hulu. Kemudian untuk wilayah potensi bencana longsor yang rendah berada pada wilayah DAS bagian tengah hingga ke hilir. Adapun untuk potensi bencana longsor yang sedang, terdapat pada batas antara kawasan DAS hulu dan DAS tengah. Adanya pendeteksian bencana longsor yang akan terjadi di lokasi ini, maka tentu hal ini menjadi sangat perlu untuk dijadikan sebagai dasar pertimbangan sebelum menentukan kebijakan pengelolaan DAS Binanga Lumbua untuk lebih prioritas memperhatikan ekosistem DAS bagian hulu untuk menjaga stabilitas penyaluran air hinggi ke hilir.

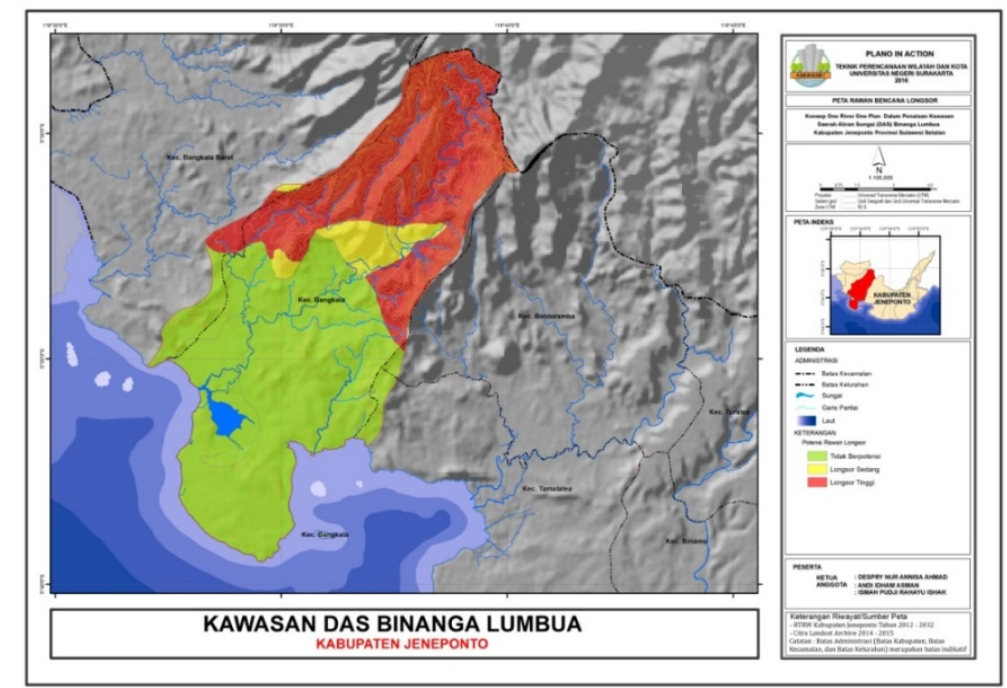

Gambar 3. Peta Potensi Bencana Longsor 
2. Hasil Analisis Pemetaan Bencana Banjir

Berdasarkan hasil analisis spasial yang dilakukan, wilayah DAS yang memiliki potensi bencana banjir yang tinggi, yakni berada pada bagian Hilir DAS, tepat pada muara sungai utama berada. Hasil analisis spasial ini sejalan dengan kondisi data kejadian bencana banjir yang pernah terjadi pada tahun 2014 sebelumnya di titik lokasi tersebut.

Berdasarkan ketiga data hasil analisis spasial dari potensi bencana yang telah dilakukan, maka dilakukan analisis fungsi kawasan untuk menentukan arahan pemanfaaatan ruang yang harus dilakukan pada kawasan DAS Binanga Lumbua. Hasil analisis fungsi kawasan tersebut dapat dilihat pada Gambar 10 berikut.

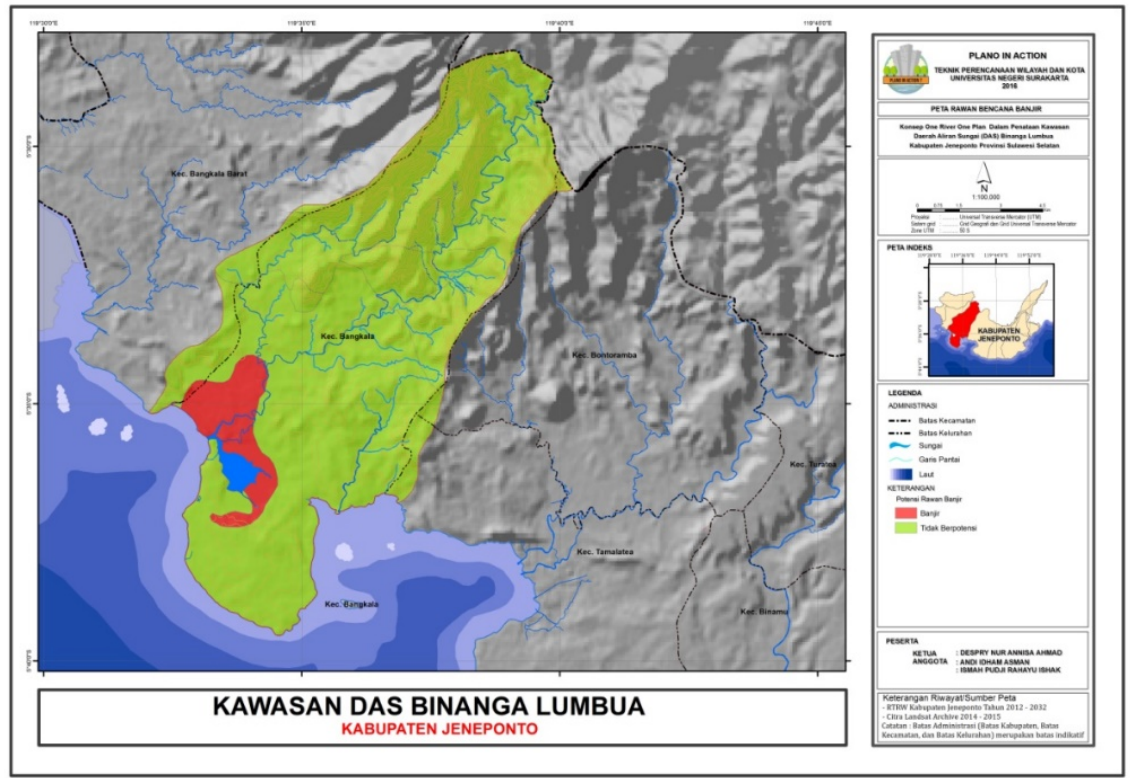

Gambar 4. Peta Potensi Bencana Banjir

Berdasarkan hasil overlay yang dilakukan pada seluruh parameter arahan fungsi kawasan di DAS Binanga Lumbua, dapat diketahui bahwa arahan pemanfaatan lahan yang paling dominan untuk kemudian di implementasikan di Kawasan DAS Binanga Lumbua adalah berupa kawasan penyangga.

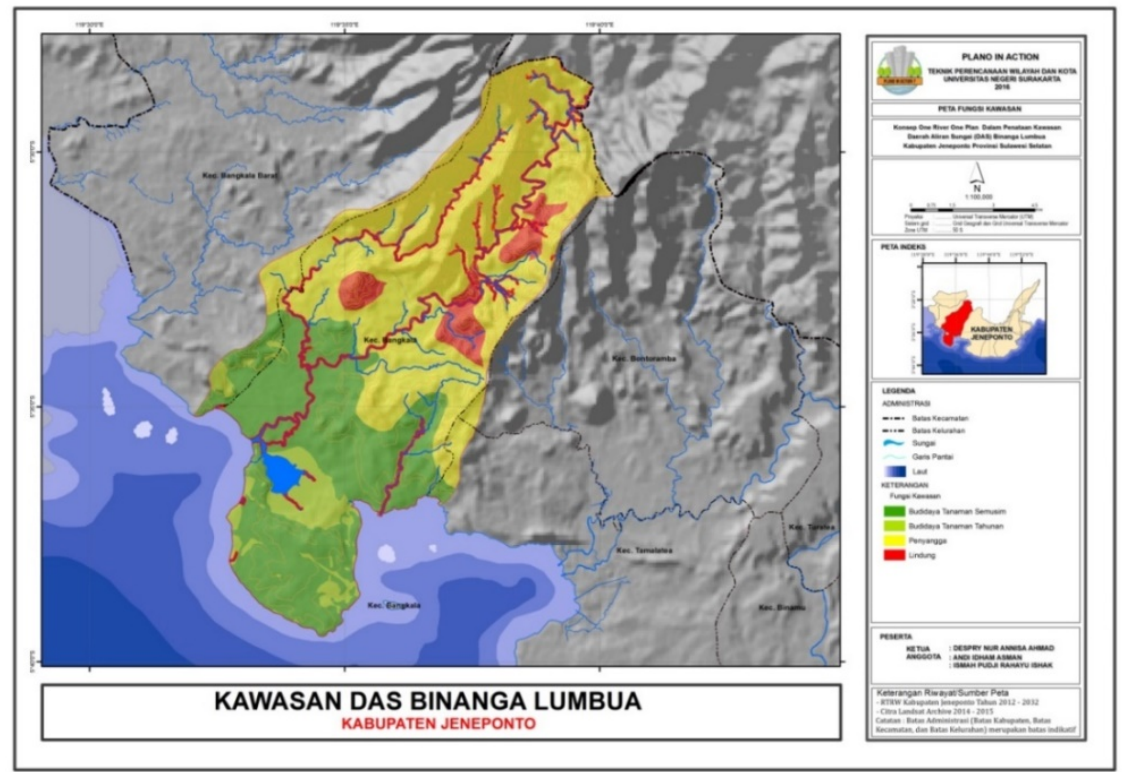

Gambar 5. Peta Fungsi Kawasan 
Kawasan fungsi penyangga adalah suatu wilayah yang berungsi sebagai pelindung dan sebagai budidaya. Letaknya diantara kawasan lindung dan kawasan budidaya seperti hutan produksi terbatas, perkebunan tanaman keras, perkebunan campuran dan lain-lainnya yang sejenis. Pada kawasan ini tidak dibolehkan mengeksploitasi besar-besaran vegetasi-vegetasi yang ada sehingga dibutuhkan upaya pengawasan dalam tahap implementasinya. Kemudian untuk arahan pemanfaatan kawasan lindung diarahkan pada puncak-puncak bukit dan sempadan sungai. Kawasan fungsi lindung ini merupakan kawasan yang sifat fisiknya mempunyai fungsi lindung untuk kelestarian sumberdaya alam, flora dan fauna seperti hutan lindung, hutan suaka, hutan wisata, daerah sekitar sumber mata air dan alur sungai, serta kawasan lindung lainnya. Sedangkan untuk arahan budidaya kawasan budidaya tanaman tahunan dan budidaya tanaman semusim diarahkan pada bagian hilir DAS. Luas masing-masing pemanfaatan ruang berdasarkan fungsi kawasan dapat dilihat pada Tabel 13 berikut.

Tabel 24. Arahan Pemanfaatan Ruang di DAS Binanga Lumba

\begin{tabular}{|c|l|c|c|}
\hline No & \multicolumn{1}{|c|}{ Fungsi Kawasan } & Luas Wilayah & Persentase \\
\hline 1 & Kawasan Lindung & 601 & 5 \\
\hline 2 & Kawasan Penyangga & 7039 & 54 \\
\hline 3 & Kawasan Budidaya Tanaman Tahunan & 4846 & 37 \\
\hline 4 & Kawasan Budidaya Tanaman Semusim & 572 & 4 \\
\hline \multicolumn{2}{|c|}{ Jumlah } & 13058 & 100 \\
\hline
\end{tabular}

Sumber: Hasil Analisis Tahun 2016

Berdasarkan tabel 24, dapat diketahui bahwa arahan pemanfaatan ruang di kawasan DAS Binanga Lumbua berdasarkan hasil analisis kesesuaian lahan terbagi dalam 4 fungsi kawasan, yaitu kawasan budidaya tanaman tahunan seluas $4846 \mathrm{Ha}$ atau $37 \%$ dari luas keseluruhan DAS. Kawasan budidaya tanaman semusim sebesar 4\% dari luas total atau seluas 572 Ha. Kawasan lindung memiliki luasan terendah, yaitu $601 \mathrm{Ha}$ atau 5\% saja dari luas total kawasan. Fungsi kawasan penyangga memiliki luas wilayah terbesar yaitu $7039 \mathrm{Ha}$ atau 54\% dari luas total DAS Binanga Lumbua.

Mengacu pada hasil analisis fungsi kawasan, maka analisis selanjutnya dilanjutkan lagi dengan melakukan pendetilan skala fungsi kegiatan. Selain mengacu pada analisis fungsi kawasan, alokasi fungsi kegiatan ini dilakukan berdasarkan arahan pemanfaatan ruang dari RTRW Kabupaten Jeneponto 2011-2031. Peta inilah yang kemudian dinamakan peta konsep penerapan one river one plan karena proses pembuatannya juga dilakukan dengan menyertakan potensi bencana, peta fungsi kawasan, dan peta rencana pola pemanfaatan ruang RTRW Kabupaten Jeneponto Tahun 2011-2031. Sajian peta arahan konsep one river one plan ini dapat dilihat pada Gambar 14 di halaman 24 berikut.

Konsep one river one plan ini merupakan suatu konsep komperehensif yang dapat digunakan untuk menerapkan satu rencana untuk satu satuan wilayah sungai. Dikatakan komprehensif karena dibuat berdasarkan masalah, fungsi kawasan dan disesuaikan dengan dokumen perencanaan kabupaten (RTRW). Khusus pada penelitian ini, permasalahan DAS difokuskan pada permasalahan bencana. Bencana tersebut adalah kekeringan, banjir, dan longsor.

\section{PENUTUP}

Kesimpulan berdasarkan uraian pembahasan pada bab sebelumnya, maka kesimpulan dalam paper ini adalah konsep one river one plan merupakan suatu konsep komperehensif yang dapat digunakan untuk menerapkan satu rencana untuk satu satuan wilayah sungai. Perencanaannya dibuat berdasarkan permasalahan yang terjadi, analisis fungsi kawasan dan penyesuaian dengan dokumen perencanaan kabupaten (RTRW). 
Saran yang dapat diberikan adalah diperlukannya koordinasi yang baik antara pemerintah, swasta, dan masyarakat dalam mewujudkan perencanaan dan pengelolaan daerah aliran sungai yang berkelanjutan.

\section{DAFTAR PUSTAKA}

Amin, M., Sarino, S., \& Sari, N. K. (2015). Visualisasi Potensi Genangan Banjir di Sungai Lambidaro Melalui Penelusuran

Aliran Menggunakan HEC-RAS Studi Pendahuluan Pengendalian Banjir Berwawasan Lingkungan. Arsyad, S. 1989. Konservasi Tanah dan Air. Bogor: IPB Press

Bach, Hanne., Clausen, Torkil. Trang, Dang Thuy., Lucy Emerton., Facon, Thierry., Hofer, Thomas., Lazarus,Kate., Muzial,Christoph., Noble,Andrew., Schill,Petra., Sisouvanh., Wensley,Christoper., dan Whiting, Louise. 2011. From Local Watershed Management to Integrated River Basin Management at National and Transboundary Levels. Mekong River Comission: Vientiane, Laos.

Eryani, P. (2014). Potensi Air dan Metode Pengelolaan Sumber Daya Air di Daerah Aliran Sungai Sowan Perancak Kabupaten Jembrana. PADURAKSA: Jurnal Teknik Sipil Universitas Warmadewa, 3(1), 3241.

Fisu, A. A. (2016). Potensi Demand Terhadap pengembangan Kanal Jongaya \& Panampu Sebagai Moda Transportasi (Waterway) di Kota Makassar. Jurnal Manajemen Transportasi \& Logistik, 3(3), 285-298.

Halim, F. (2014). Pengaruh hubungan tata guna lahan dengan debit banjir pada Daerah Aliran Sungai Malalayang. Jurnal Ilmiah Media Engineering, 4(1)

Turu, M. (2016). Analisa Keseimbangan Air pada Daerah Irigasi Salobunne Kabupaten Soppeng. PENA TEKNIK: Jurnal Ilmiah Ilmu-ilmu Teknik, 1(1), 13-18.

Van Noordwijk, M., Agus, F., Suprayogo, D., Hairiah, K., Pasya, G., Verbist, B., \& Farida, A. (2014). Peranan agroforestri dalam mempertahankan fungsi hidrologi daerah aliran sungai (DAS). Jurnal AGRIVITA.(26), 1.

Wani, Suhas P dan Garg Kaushal K. 2008. Watershed Management Concept and Principles. International Crops Research Institute for the Semi-Arid Tropics (ICRISAT) Patancheru: India

Yen, H., Bailey, R. T., Arabi, M., Ahmadi, M., White, M. J., \& Arnold, J. G. (2014). The role of interior watershed processes in improving parameter estimation and performance of watershed models. Journal of Environmental Quality, 43(5), 1601-1613. 